\title{
5 The structure and characteristics of East Asian bondmarkets
}

\author{
S. Ghon Rhee
}

The definition of the term 'East Asian bondmarkets' is elusive at best, and so it must be asked, 'What is a regional bondmarket?' This question, in turn, raises a series of related questions.

- Is this a market geographically confined to the East Asian region?

- Do issuers, buyers, underwriters and market makers all come from the same region?

- Are regional bonds to be denominated in one of Asia's currencies or in a basket of Asian currencies?

- If they are denominated in the US dollar or the euro, are they still classified as regional bonds?

- Do we expect regional bonds to be rated only by Asian rating agencies? Do we expect regional bonds to be traded only in the region?

- Finally, does it make sense to pursue a regional program when the global financial community is becoming increasingly integrated?

Before these questions are addressed, a reality check is in order to make sure we have a comprehensive understanding of the current status of regional market activities.

Fact 1. From an examination of 71 bonds with a combined face value of US $\$ 41.2$ billion, issued by Asian borrowers (banks, corporations and sovereign/quasisovereign issuers from China, Hong Kong SAR, Indonesia, Korea, Malaysia, the Philippines, Singapore and Chinese Taipei) during the period April 1999August 2002, McCauley, Fung and Gadanecz (2002) report that 44-46 per cent of these bonds were purchased by Asian investors in the primary market offering. They further observe that Asian borrowers usually rely on affiliates of US or European investment banking firms for book-running and assembling 
syndicates of underwriters, and that larger issues and longer maturities are placed outside the region. They conclude that East Asia's bondmarket activities are far more integrated than is often perceived.

Fact 2. Singapore is a small but important part of East Asia's bondmarkets. The market activities of its onshore market for Singapore dollar-denominated bonds and offshore market (known as the Asian Dollar Market) for foreign currency-denominated bonds are useful in assessing the degree of regional integration of financial transactions. Until August 1998, foreign institutions were not allowed to issue Singapore dollar-denominated bonds in Singapore due to the Monetary Authority of Singapore's policy of discouraging the internationalisation of Singapore dollars. However, in order to promote Singapore as a regional financial centre, this policy was relaxed and foreign corporations allowed to issue Singapore dollar-denominated bonds in Singapore on the condition that the proceeds were to be used for economic expenditure within Singapore; otherwise, the proceeds had to be swapped for a foreign currency within Singapore. After the policy change, the total issuance of Singapore dollar-denominated bonds by foreign issuers increased to $\$ \$ 2.70$ billion in 1999, $\$ \$ 2.57$ billion in $2000, \$ \$ 1.83$ billion in 2001 and $\mathrm{S} \$ 3.22$ billion in 2002 (Figure 5.1). ${ }^{1} \mathrm{~A}$ total of 27 per cent of the issuers were from the Asia Pacific region, whereas the majority of foreign borrowers were

\section{Figure 5.1 New issues of Singapore dollar-denominated bonds by foreign entities, 1999-2002}

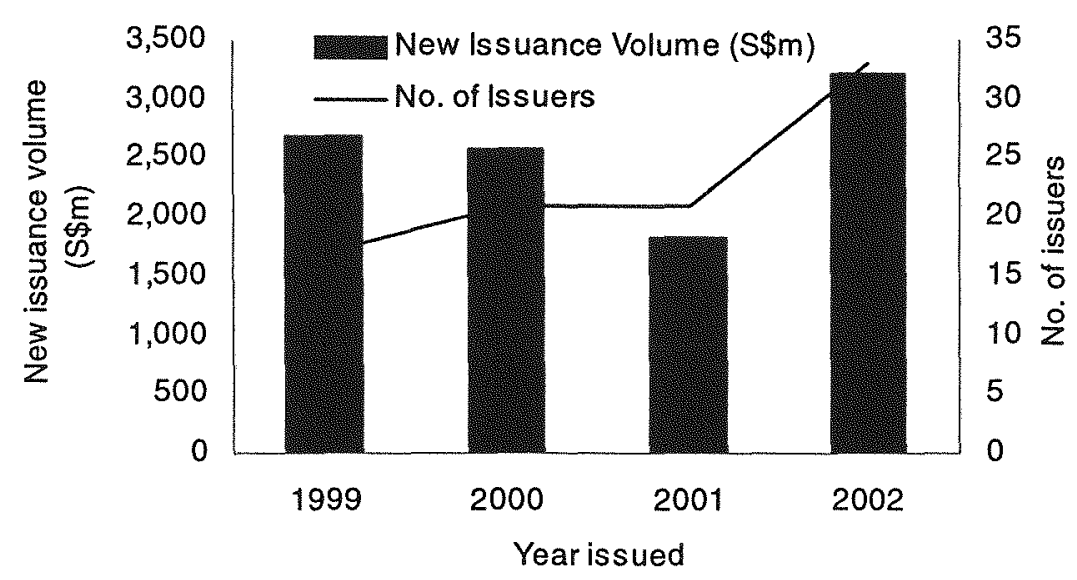

Source: Monetary Authority Singapore, 2003. Survey of the Singapore Corporate Debt Market, Monetary Authority of Singapore, Singapore. Available online at http:// www.mas.gov.sg/singfinsec/download/2002DebtSurvey.pdf. 
from the United States and Europe (Monetary Authority of Singapore 2003) (see Figure 5.2). While the bulk of Singapore dollar debt instruments issued by foreign borrowers were placed with onshore Singapore investors, the proportion of Singapore dollar debt bought by offshore investors increased from 1 per cent in 2001 to 10 per cent in 2002 (Figures 5.1,5.2,5.3).

The total amount of offshore Asian Dollar Market debt issued in 2002 and 2001 amounted to US\$10.9 billion and US\$27.1 billion, respectively (Figure 5.4). At least 40 per cent of the borrowers in the Asian Dollar Market were financial institutions and corporations from the Asia Pacific region.

Figure 5.2 Geographical distribution of foreign issuers: Singapore dollardenominated bonds (per cent)

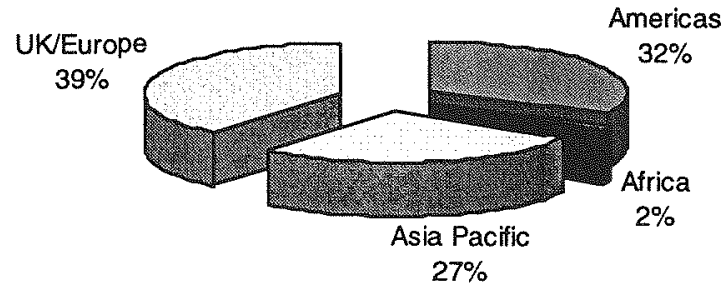

Source: Monetary Authority Singapore, 2003. 2002 Survey of the Singapore Corporate Debt Market, Monetary Authority of Singapore, Singapore. Available online at http:// www.mas.gov.sg/singfinsec/download/2002DebtSurvey.pdf.

Figure 5.3 Types of foreign issuers of Singapore dollar-denominated bonds (per cent)

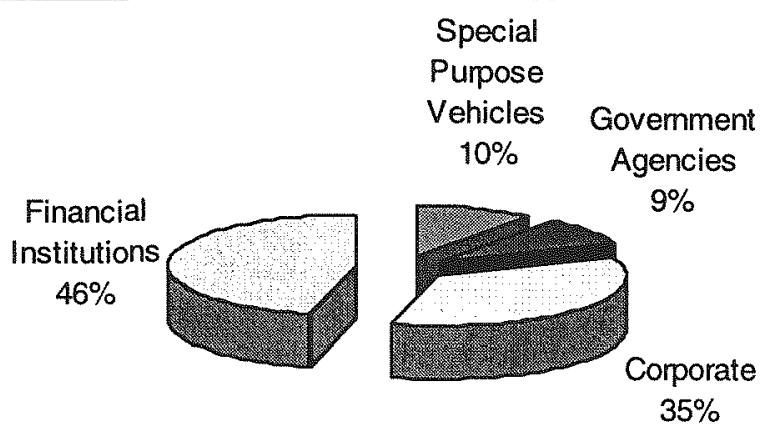

Source: Monetary Authority Singapore, 2003. 2002 Survey of the Singapore Corporate Debt Market, Monetary Authority of Singapore, Singapore. Available online at http:// www.mas.gov.sg/singfinsec/download/2002DebtSurvey.pdf. 
Figure 5.4 Non-Singapore dollar bond issuance, 1997-2002 (S\$ billion)

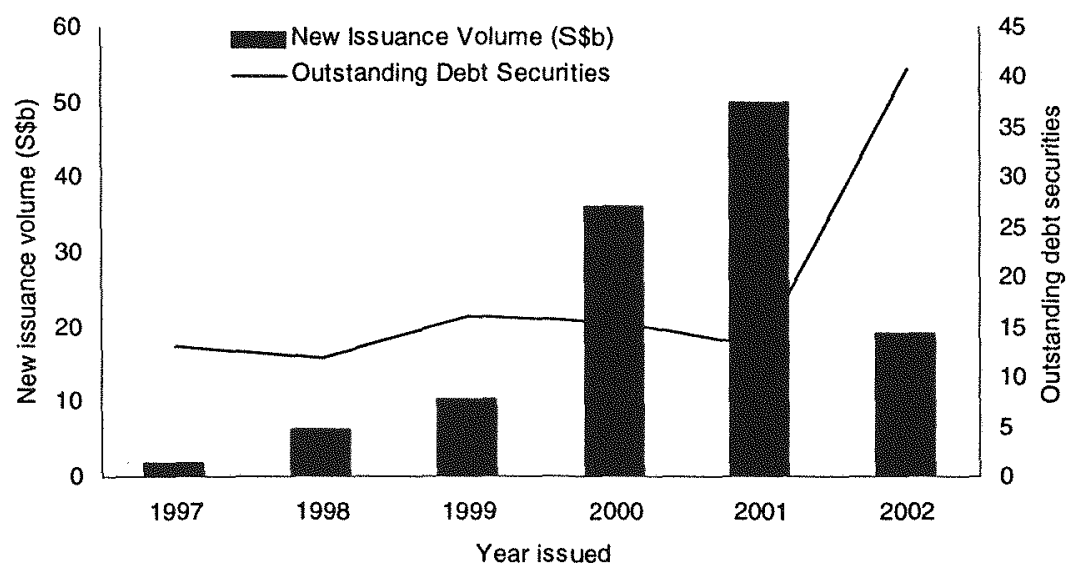

Source: Monetary Authority of Singapore, 2003. 2002 Survey of the Singapore Corporate Debt Market, Monetary Authority of Singapore, Singapore. Available online at http:// www.mas.gov.sg/singfinsec/download/2002DebtSurvey.pdf.

Figure 5.5 Non-Singapore dollar bond issues, by maturity, 2001-2002 (S\$ million)

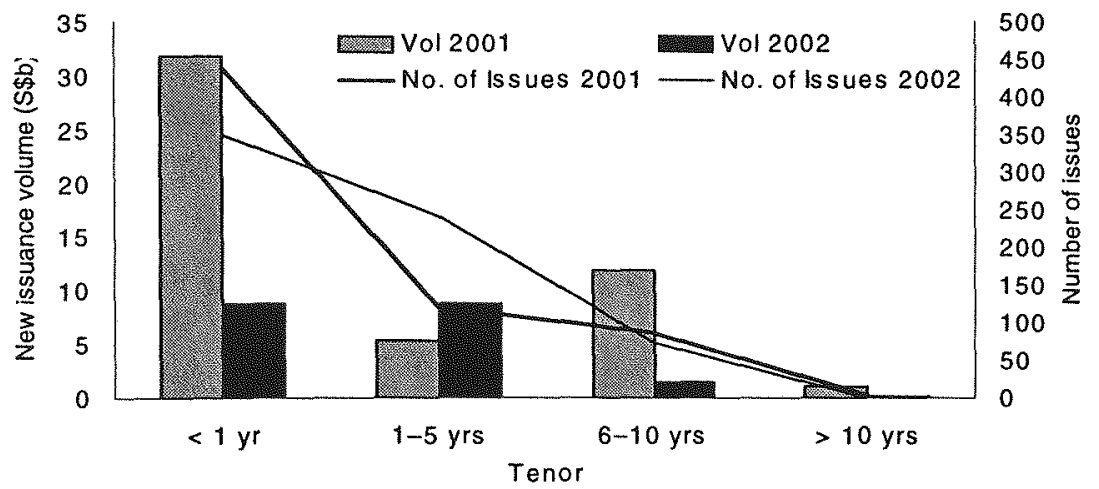

Source: Monetary Authority of Singapore, 2003. 2002 Survey of the Singapore Corporate Debt Market, Monetary Authority of Singapore, Singapore. Available online at http:// www.mas.gov.sg/singfinsec/download/2002DebtSurvey.pdf. 
Approximately 92 per cent of non-Singapore dollar debt was sold to offshore investors. All debt issues in the Asian Dollar Market were private placements. ${ }^{2}$ US dollars continued to dominate the Asian Dollar Market debt issues but its proportion of total amount of issuance declined from 92 per cent in 2001 to 76 per cent in 2002. Japanese yen and Hong Kong dollars followed with 15 per cent and 6 per cent, respectively. It appears that the Asian Dollar Market functions as a short-term market (mostly less than one-year maturity) for Asian financial institutions (Figures 5.4, 5.5, 5.6, 5.7).

\section{Figure 5.6 Types and geographical distribution of non-Singapore dollar issuers (per cent)}

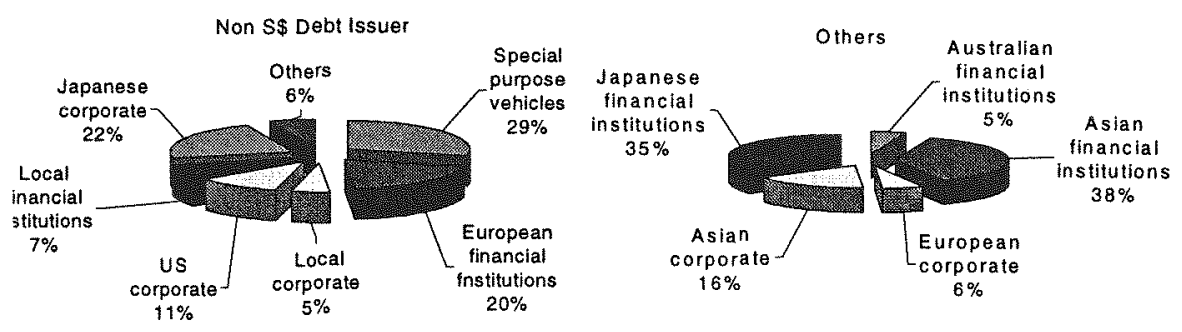

Source: Monetary Authority of Singapore, 2003. 2002 Survey of the Singapore Corporate Debt Market, Monetary Authority of Singapore, Singapore. Available online at http:// www.mas.gov.sg/singfinsec/download/2002DebtSurvey.pdf.

Figure 5.7 Currency denomination of non-Singapore dollar bond (per cent)

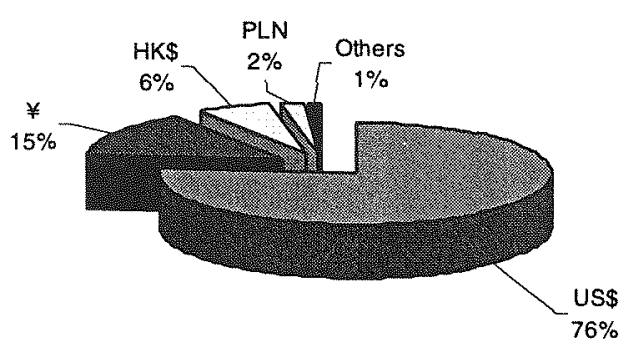

Note: Others includes A\$, CA $\$$, euro, $£, N Z \$$ and STG

Source: Monetary Authority of Singapore, 2003. 2002 Survey of the Singapore Corporate Debt Market, Monetary Authority of Singapore, Singapore. Available online at http:// www.mas.gov.sg/singfinsec/download/2002DebtSurvey.pdf. 
Fact 3. According to Bae and Park (2002), borrowers from six Asian countries (Indonesia, Korea, Malaysia, the Philippines, Chinese Taipei and Thailand) raised US $\$ 52.6$ billion through bond financing outside their jurisdictions during the 11-year period 1991-2001. US and European investment banks served as lead managers for two-thirds of this amount and the remaining one-third was led by their Asian counterparts. The market share of Asian investment banks appears surprisingly large in view of the fact that 18 of the top 20 lead managers in the global investment banking business are US or European banks.

Fact 4. In the East Asian region, only Hong Kong SAR and Singapore are open to international bond rating agencies without domestic counterparts. All other Asian economies, including Indonesia, Japan, Korea, Malaysia, Philippines, Chinese Taipei and Thailand have their own bond-rating agencies. International accounting standards have been adopted for listed companies' reporting in most of the Asian economies, with the exception of China, Indonesia and Philippines (Table 5.1).

Fact 5. The Shogun bond (foreign currency-denominated bonds issued in Japan by foreign borrowers) market is Tokyo's offshore market, while the Samurai bondmarket (yen-denominated bonds issued in Japan by foreign borrowers) is the onshore market. Unfortunately, Shogun bonds have not been issued since 1994. The issuance volume of Samurai bonds peaked prior to the East Asian financial crisis in 1996 at 3.8 trillion yen, then declined following the crisis to 0.15 trillion yen in 1998 and 0.87 trillion yen and 1999. In 2000, the market recovered somewhat and Samurai bond issuance rose to 2.38 trillion yen, which was still below the peak pre-crisis level of 1996. Despite low interest rates in Japan, the issuance volume of Samurai bonds was only 0.64 trillion yen in 2002 (Table 5.2).

Fact 6. Dragon bonds issued by international financial institutions such as the World Bank and the Asian Development Bank are not liquid on the secondary market. Asian financial institutions buy these bonds on the primary market to take advantage of the withholding tax exemption and usually hold the bonds until maturity, raising questions about their contribution to the development of the region's bondmarkets.

The findings of McCauley et al. (2002) and the recent activities of Singapore's onshore and offshore bondmarkets indicate that Asian borrowers rely on US and European investment banks to tap global financial markets (mostly in London and New York), but that at least 40 per cent of these bonds end up in Asian portfolios. Why then is it so urgent to develop regional bondmarkets? This particular question cannot be separated from the definition of a regional bondmarket. 
Table 5.1 Regional bond rating agencies

\begin{tabular}{llc}
\hline Number of domestic CRAs & $\begin{array}{c}\text { Adoption of IAS } \\
\text { statements by SEs }\end{array}$ \\
China & Open to global CRAs & Yes \\
Hong Kong SAR & None & No \\
Indonesia & Open to global CRAs & Yes \\
Japan & 2 & No \\
Korea & 3 & Yes \\
Malaysia & 3 & Yes \\
Philippines & 2 & Yes \\
Singapore & 1 & No \\
Chinese Taipei & Open to global CRAs & Yes \\
Thailand & 1 & Yes \\
\end{tabular}

Source: Author's calculations.

Table 5.2 Gaisai bond issues, 1991-2002 (yen trillion)

\begin{tabular}{lccrr}
\hline & $\begin{array}{c}\text { Number of } \\
\text { issues }\end{array}$ & $\begin{array}{c}\text { Samurai } \\
\text { bonds }\end{array}$ & $\begin{array}{c}\text { Number of } \\
\text { issues }\end{array}$ & $\begin{array}{c}\text { Shogun } \\
\text { bonds }\end{array}$ \\
1991 & 27 & 0.71 & 1 & 0.41 \\
1992 & 37 & 1.57 & - & - \\
1993 & 49 & 1.23 & 1 & 0.59 \\
1994 & 60 & 1.26 & - & - \\
1995 & 85 & 2.11 & - & - \\
1996 & 154 & 3.79 & - & - \\
1997 & 66 & 1.58 & - & - \\
1998 & 10 & 0.15 & - & - \\
1999 & 24 & 0.87 & - & - \\
2000 & 63 & 2.38 & - & - \\
2001 & 47 & 1.55 & - & - \\
2002 & 29 & 0.64 & - & - \\
& & & & - \\
\hline
\end{tabular}

Source: Japan Securities Dealers Association. 


\section{What do we mean by regional bondmarkets?}

The creation of a regional bondmarket became a popular subject of discussion among financial market policymakers after the East Asian financial crisis of 1997-98. The single most dramatic element of the crisis was the abrupt reversal of private capital flows to the five crisis-affected economies (Indonesia, Korea, Malaysia, Philippines and Thailand) within a period of several months. In retrospect, however, the amount of the reversal-slightly greater than US\$100 billion-was not too large for the region's economies as a group to handle. This amount accounted for less than 5 per cent of the combined pre-crisis domestic savings of the five crisis-affected economies and the five leading economies in the region (China, Hong Kong SAR, Japan, Singapore and Chinese Taipei) and only about 15 per cent of the total foreign exchange reserves accumulated by these 10 economies. Now that the accumulated foreign exchange reserves in the region are approaching US\$1.5 trillion, or more than one-half of the world's foreign exchange reserves, the amount of the reversal which triggered the 1997-98 crisis seems trivial.

The region's policymakers have realised that had these savings been channelled into corporate financing without a reliance on short-term bank financing from outside the region, and had only 15 per cent of the accumulated reserves been allocated toward the capital account crises, the consequences of the East Asian financial crisis might have been very different. The former condition relating to savings mobilisation calls for the development of a wellfunctioning domestic bondmarket in each of Asia's economies, while the latter condition requires region-wide coordination on the systematic establishment of a pool of foreign exchange reserves available for an economy facing a similar capital account crisis.

In regards to the development of infrastructure for primary and secondary bondmarkets, remarkable progress has been made in each of the East Asian economies since the 1997-98 crisis. (See Appendix 5.1 for an outline of this progress with a focus on Hong Kong, Japan and Singapore.) The Chiang Mai Initiative proposed by ASEAN+3 finance ministers in May 2000 was a direct response to the call for regional cooperation on the mobilisation of foreign exchange reserves. Under this initiative, a series of bilateral currency swap arrangements among the ASEAN +3 countries is to be created, expanding swap arrangements of smaller scale that already exist among ASEAN members. However, the efficacy of this initiative has yet to be tested because of the potential overlapping of International Monetary Fund assistance programs. That is, the precondition for bilateral swap arrangements requires that the borrowing party should already be under or be about to come under the International Monetary Fund assistance program, ${ }^{3}$ and the policy of 'strategic 
ambiguity' adopted by ASEAN +3 as well as by the International Monetary Fund and senior officials of the US Treasury makes it unclear how ASEAN+3 swap arrangements and the International Monetary Fund's supplemental reserve facility would be coordinated. ${ }^{4}$ Such uncertainty and opacity simply add to concerns about the potential 'moral hazard' of the swap arrangements.

Where does a regional bondmarket fit in? We know that a regional market cannot substitute for a domestic bondmarket because a domestic bondmarket is one of three major vehicles for domestic savings mobilisation in any country, along with bank financing and equity financing. We also know that a regional bondmarket is one thing and a regional system of mobilising foreign exchange reserves is another. Now we have to think about exactly what we mean by a regional bondmarket. The narrowest definition of an East Asian bondmarket is represented by the union of the three circles signifying Asian issuers, Asian investors and Asian currencies. It may be expanded to include another circle denoting Asian investment banks. This produces an even narrower union of four circles. We may go one step further and require that all bond financing activities occur in Asian financial centres. Does it make any sense to pursue this kind of extreme regionalism? In reality, extreme regionalism comes at substantial cost. In the worst-case scenario, any effort oriented toward extreme regionalism will simply force all financing activities to move outside the region for lower-cost funding alternatives (Figure 5.8).

Figure 5.8 Regional bondmarket

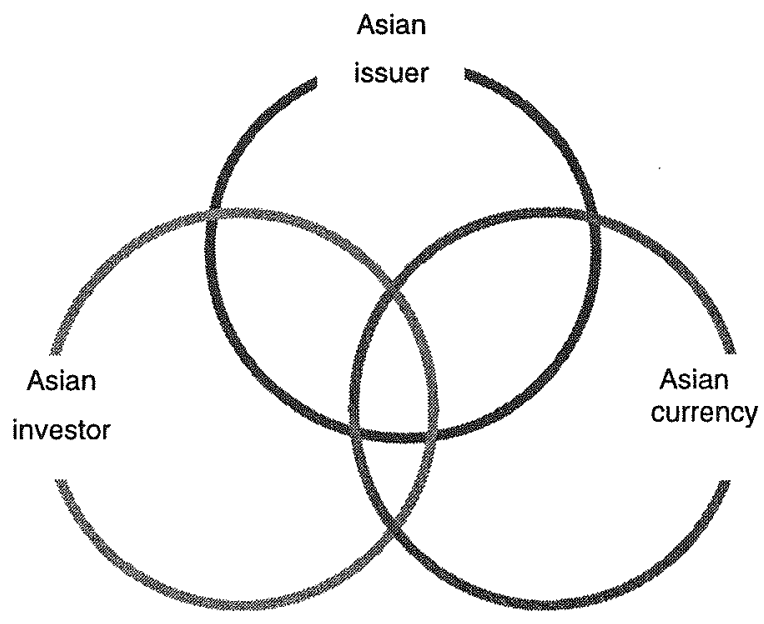


As long as Asian borrowers issue bonds at a minimum cost and the majority of these bonds are purchased by Asian investors, allowing them to gain the maximum yield, all other considerations are secondary. It does not matter where these bonds are issued, who rates them, who serves as the lead manager, where the bonds are traded or where they are cleared and settled. Given all this, the distinction between regional bonds and global bonds becomes either unimportant or irrelevant, because bonds issued by Asian borrowers in New York or Frankfurt can be purchased by investors in Asia. However, there are two major considerations that stand out and make the distinction between regional and global markets meaningful: credit enhancement programs and the Asian common currency.

Credit enhancement programs are necessary to assist Asian governments, semi-governmental agencies and corporate issuers that have received relatively low credit ratings from international credit agencies so that they can issue bonds at an affordable cost, if not at minimum rates (Table 5.3). So far, however, only minimal efforts have been undertaken by the region's economies to implement credit enhancement programs to facilitate bond issuance by Asian borrowers. ${ }^{5}$ In a keynote address delivered at the ASEAN+3 High-Level Seminar on 'Fostering Bond Markets in Asia', Taniguchi (2003) suggested that the Asian Development Bank and the Japan Bank for International Cooperation provide credit guarantees to corporate and sovereign borrowers in Asia. ${ }^{6}$ In a parallel paper, Rhee and Stone (2003) proposed that regionwide credit enhancement programs adopt the concept of municipal bond banks to gain the benefit of credit rating arbitrage and economies of scale by pooling the funding needs of Asian borrowers.

The creation of an Asian common currency and its use in denominating regional bonds has been widely debated, but so far very little progress has been made. The most significant development arising from the launch of the euro has been the integration of European financial markets. A strong convergence of short-term interest rates quickly created a liquid money market for the entire euro zone, while longer-term bondmarkets in Europe have exhibited some degree of market integration, as indicated by the decline of interest rate spreads among the 11 participating countries. The elimination of exchange risk, the harmonisation of market practices and the redenomination of government debt into euro-denominated debt have heralded the emergence of a bigger, deeper, more liquid and more homogeneous bondmarket for Europe (Quaden 1999, Duisenberg 1999). Similar advantages may be gained in Asia through full or partial currency unification as a result of common or partially shared monetary policies among the region's economies. 
Table 5.3 Sovereign credit rating, June 2003

\begin{tabular}{lcc} 
& Local currency & Foreign currency \\
China &. & BBB \\
Hong Kong SAR & $\mathrm{AA}-$ & $\mathrm{A}+$ \\
India & $\mathrm{BB}+$ & $\mathrm{BBB}$ \\
Indonesia & $\mathrm{BB}+$ & $\mathrm{B}-$ \\
Korea & $\mathrm{A}+$ & $\mathrm{A}-$ \\
Malaysia & $\mathrm{A}+$ & $\mathrm{BBB}+$ \\
Mongolia & $\mathrm{B}$ & $\mathrm{B}$ \\
Philippines & $\mathrm{BBB}$ & $\mathrm{BB}$ \\
Singapore & $\mathrm{AAA}$ & $\mathrm{AAA}$ \\
Chinese Taipei & $\mathrm{AA}-$ & $\mathrm{AA}-$ \\
Thailand & $\mathrm{A}-$ & $\mathrm{BBB}$ \\
Vietnam & $\mathrm{BB}$ & $\mathrm{BB}$ \\
\hline
\end{tabular}

Source: Standard \& Poors', June 2003.

\section{Table 5.4 Foreign holders of US Treasury securities, 2001-2003} (US\$ billion)

\begin{tabular}{lccc}
\hline & March & December & December \\
& 2003 & 2002 & 2001 \\
Japan & 386.6 & 364.7 & 317.9 \\
China & 117.7 & 102.9 & 78.6 \\
Hong Kong SAR & 49.8 & 48.1 & 47.7 \\
Korea & 41.8 & 43.1 & 32.8 \\
Chinese Taipei & 34.5 & 34.5 & 35.3 \\
Singapore & 18.5 & 17.8 & 20.0 \\
Thailand & 13.3 & 16.3 & 15.7 \\
Total Asia (per cent) & 662.2 & 627.6 & 521.3 \\
Total foreign (per cent) & $1,242.5$ & $1,204.5$ & $1,040.1$ \\
& \multicolumn{4}{l}{} \\
\hline Source: Department of the Treasury/Federal Reserve Board, 2004. Major foreign \\
holders of Treasury securities, statistical table produced by Treasury International \\
Capital System, United States Department of the Treasury, Washington, DC. Available \\
online at http://www.ustreas.gov/tic/mfh.txt. \\
\hline
\end{tabular}




\section{Recent proposals - the Asian Bond Fund and Asian basket currency bonds}

With the region's combined foreign exchange reserves reaching US\$1.5 trillion, the practical merits of diversifying the investment holdings of central banks in the region should be considered. At the end of March 2003, seven East Asian economies (China, Hong Kong SAR, Japan, Korea, Singapore, Chinese Taipei and Thailand) were holding US Treasury securities with a total value of US $\$ 662.2$ billion, or 20 per cent of total outstanding US Treasury securities and one-half of total foreign holdings of US Treasury securities (Table 5.4). This amount is approximately 40 per cent of foreign exchange reserves accumulated in the East Asian economies, and the reserve holdings far exceed the requirements for exchange rate management or import coverage (Lim 2003). Two notable recent regional-level efforts in this direction are the Asian Bond Fund and Asian basket currency bonds.

In June 2003, the Executives' Meeting of East Asia and Pacific Central Banks (EMEAP) announced the launch of the Asian Bond Fund with an initial size of US $\$ 1$ billion. The ABF will invest in a basket of US dollardenominated bonds issued by Asian sovereign and quasi-sovereign issuers in all EMEAP countries except Japan, Australia and New Zealand. ${ }^{8}$ The fund will be managed by the Bank for International Settlements. The EMEAP Group also indicated that it would review the extension of the Asian Bond Fund concept to include bonds denominated in Asian currencies.

Ito (2003b) proposes that an Asian Bond Corporation be established to serve as a depository for financial assets supplied by participating governments and to issue bonds that match the value of the assets. ${ }^{9}$ The financial assets supplied by the participating governments would be local currency-denominated government bonds. In the second phase of development, the Asian Bond Corporation would be able to issue bonds that matched the value of corporate bonds denominated in various Asian currencies. The Asian Bond Corporation would function like a special purpose vehicle in an asset-backed securities scheme.

The concept of $\mathrm{ABC}$ bonds is simple because it borrows the idea of assetbacked securities, and it is intuitively appealing because it may serve as the precursor to an Asian common currency. While the Asian Bond Fund simply serves as a buyer of US dollar-denominated bonds issued by regional borrowers using the funds pooled by the region's central banks, the Asian Bond Corporation serves as an issuer of bonds that match the value of underlying assets denominated in government bonds and in various Asian currencies. When pooled, cash flows from pledged bonds (interest and scheduled repayment of principal) are distributed on a pro rata basis to the holders of the $\mathrm{ABC}$ bonds. Thus, the Asian Bond Corporation is effectively 
issuing pass-through securities. Although underlying pledged bonds are guaranteed by the full faith and credit of participating Asian governments, credit rating-related problems arise because not all governments enjoy the highest credit ratings from international rating agencies. Thus, credit enhancements will be needed even when government bonds are pledged. When corporate bonds are pledged as underlying assets, credit enhancements are a must, with two types being utilised-external enhancements and internal enhancements.

External enhancements include third-party guarantees, letters of credit and bond insurance. Third-party guarantees may be provided by official financial institutions such as the Asian Development Bank, the Japan Bank for International Cooperation and the Development Bank of Singapore. Letters of credit may be provided by leading commercial banks of international stature. A number of monoline bond insurance companies are in operation in the United States and Europe, which offer municipal bond insurance and pool insurance (Table 5.4). ${ }^{10}$

The most common form of internal enhancement involves the creation of senior/subordinated structures of pooled cash flows of pledged assets. ${ }^{11} \mathrm{By}$ restructuring the distribution of pooled cash flows, a new instrument called a 'collateralised bond obligation' is created. ${ }^{12}$ Under the collateralised bond obligation scheme, two tranches of Asian basket currency bonds may be issued based on a pre-determined subordination level: senior bonds with higher credit rating and subordinate bonds with lower credit rating but higher yields. This type of structured bond issue became very popular in Korea in the postcrisis period (Oh et al. 2003). ${ }^{13}$

Although detailed operating procedures have yet to be designed for the Asian Bond Fund and Asian basket currency bonds, they do represent a good beginning and should draw the attention of financial market policymakers in the East Asian region to the need for credit enhancement programs and an Asian common currency. Another critical aspect which has often been overlooked is the liquidity of bonds on the secondary market. Neither the Asian Bond Fund nor the Asian Bond Corporation proposal can say much about this issue. With the Asian Bond Fund serving as an investment vehicle for the region's central banks, its immediate impact will be realised in the form of increased demand for bonds issued by Asian borrowers. The Bank for International Settlements, as an investment manager for the Asian Bond Fund, may end up purchasing US dollar-denominated bonds issued by Asian sovereign or quasi-sovereign authorities in New York, London or Singapore's Asian Dollar Market. Expected purchasers of $\mathrm{ABC}$ bonds include central banks and pension funds from within the region and institutional investors both from within the region and from the industrialised economies. Since central banks and pension funds are known for their passive investment strategies, it 
is possible that neither $A B C$ bonds nor Asian Bond Fund-invested bonds will be instrumental in promoting market liquidity on the secondary market.

\section{Conclusion}

The creation of a regional bondmarket in East Asia can be justified for two reasons. First, it will facilitate credit enhancements for sovereign, quasi-sovereign, municipal and corporate borrowers. Second, it will facilitate the introduction of an Asian common currency. Without these two critical components, any efforts toward extreme regionalism are counterproductive and too costly to be rewarded in the global financial environment. Indeed, to confine primary and secondary market financial activities to the East Asian region would seem impossible, while to have only Asian homegrown-rating agencies provide rating services for bond instruments issued by Asian borrowers would be wasteful.

\section{Appendix 5.1}

\section{Reforms for the development of domestic bondmarkets}

With the banking sector still recovering from the recent crisis, Asian corporations have become less dependent on bank loans for funding and turned increasingly to capital market financing, establishing capital market reforms as an urgent policy agenda for the region's economies. Policymakers in these economies recognise that an active market in government-issued securities must precede the development of a corporate bondmarket. Many Asian economies have begun to accept fiscal deficits as necessary for the financing of bank restructuring and to adopt expansionary fiscal policy to cope with economic recession. Asian economies have therefore been reinforcing or creating market infrastructures to develop domestic government and corporate bondmarkets, thus laying essential foundations for the establishment of regional bondmarkets. ${ }^{14}$

Benchmark interest rates. The East Asian economies have demonstrated progressive attitudes toward improvement of benchmark yield curves. Traditionally, the lack of benchmark interest rates has been a major impediment to efficient pricing of financial assets and marking-to-market. For example, Korea has introduced a set of post-crisis reform measures, including consolidation of government-issued securities into treasury bonds to increase issue frequency and size, creation of the primary dealer system and elimination of arbitrary cut-off in determining winning bids in competitive auctions of government securities (Korea Securities Research Institute 2000). Hong Kong SAR, Malaysia, Philippines, Singapore, Chinese Taipei and Thailand have also concentrated on improving their benchmark yield curves either by 
extending maturities or by allowing the reopening of off-the-run issues to smooth out benchmark yield curves. ${ }^{15}$ Artificial demand for government-issued securities under regulatory or statutory requirements was relaxed to minimise distortions to the benchmark yield curve. As a result, the captive nature of primary market activities has become less severe than in the past.

Expanding the investor base. Also observed in the region are some positive developments toward expanding the investor base for fixed-income securities. Philippines introduced a small-denomination treasury bonds program for individual investors to trade on the local stock exchange. In Hong Kong SAR, Exchange Fund Notes have been listed on the stock exchange since August 1999 to accommodate retail investors' demand for risk-free securities. In the past, individual investors were not eligible for direct purchasing of government bonds on the primary market in Korea; now, however, they are qualified to participate in non-competitive auctions. As such, a total of 20 per cent of each primary issue is reserved for individual investors in Korea. In March 2003, Japan launched government bonds tailored for individual investors. ${ }^{16}$ Unlike conventional Japanese Government bonds, these bonds are redeemable one year after issue and have a minimum denomination of 10,000 yen and 10year maturity. They carry a floating rate that fluctuates with the real rate of interest on a semi-annual basis. To promote holdings of Japanese Government bonds by non-financial companies, companies with capitalisation of 100 million yen or more will be exempted from withholding tax on interest income from Japanese Government bonds. Hong Kong SAR has launched a Mandatory Provident Fund to increase the demand for local long-term fixed-income securities by approximately 1 per cent of GDP per year consecutively for six years. Korea recently allowed bank trust accounts to sell employee retirement trusts. This represents a first step toward a corporate pension system.

Increasing supply of quality bonds. On the supply side of public bonds, positive developments are observed in the region. In the past, Singapore's statutory boards did not issue bonds because they had immediate access to government budget or commercial bank loans. When this policy was changed in 1998, a number of government agencies began issuing long-term bonds. Thailand's state-owned enterprises became major suppliers of high-quality bonds (almost 90 per cent of their bonds are issued under the government's guarantee), accounting for slightly over one-third of Thai public sector bonds. The Malaysian government, on the other hand, recently proposed the establishment of a financial guarantee insurer to facilitate the issuance of corporate bonds with credit enhancement.

Improving market infrastructure. East Asian economies have made remarkable progress over the past two years in creating and reinforcing market 
infrastructures in the primary and secondary markets for government bonds. Within the primary markets, competitive auctions have become the norm and foreign banks and financial institutions have begun participating in public auctions as primary dealers. To improve the efficiency of tendering and reduce delays, electronic bidding systems were introduced in Malaysia, Philippines and Korea. In order to promote competition among credit rating businesses, Indonesia, Malaysia and Thailand have allowed the establishment of second rating agencies; meanwhile, Hong Kong SAR and Singapore permit market entry to foreign rating agencies with minimal entry barriers. Furthermore, Hong Kong SAR, Indonesia, Malaysia, Singapore and Thailand have introduced a real-time gross settlement system for government-issued securities, while corporate bonds still need to advance to the level of progress achieved by government bonds. Korea, Chinese Taipei and Thailand are currently revamping their systems. Chinese Taipei has implemented a bookentry system for scripless trading in 1998 and all book-entry government bonds are settled through the real-time gross settlement system. Japan finally introduced a new scripless settlement system for government bonds in January 2003. ${ }^{17}$ Although fixed-income securities are usually traded over the counter in the region, organised exchanges in Korea, Thailand and Indonesia have been creating their own trading systems to capture some of the over-the-counter trading volume. The Central Moneymarket Unit service was extended in Hong Kong SAR to non-Hong Kong dollar debt securities in 1996, and the linkage of the Central Moneymarket Unit with other central securities depositories in the region has since increased through a network of bilateral arrangements. Another important infrastructure project is the US dollar clearing system, which was fully implemented in December 2000 . This clearing system facilitates the settlement of US dollar transactions in Hong Kong SAR and the wider region, and eliminates the settlement risks that arise when a transaction is spread across different time zones. With the Hongkong and Shanghai Banking Corporation Limited designated as the settlement institution, the system was implemented in three phases, with the first phase covering the US dollar RTGS system, the second phase facilitating payment versus payment settlement for foreign exchange transactions between the US dollar and the Hong Kong dollar, and the third phase implementing an interface between the US dollar RTGS system and the Central Moneymarkets Unit. ${ }^{18}$ Through the operation of the Singapore Automated Clearing House, both Singapore dollar and US dollardenominated checks are cleared in Singapore. Launched in July 1998, the Monetary Authority of Singapore Electronic Payment System settles scripless Singapore government securities on an RTGS basis. With its interface to the Central Depository of the Singapore Exchange, it provides for the settlement of Singapore dollar debt securities on a delivery versus payment basis. 


\section{Notes}

1 Singapore dollar-denominated bonds issued by domestic entities are not included in the statistics reported. Singapore dollar-denominated bonds issued by foreign entities usually account for 10-20 per cent of the total Singapore dollar-denominated debt market.

2 The Monetary Authority of Singapore does not report a breakdown of Asian versus non-Asian investors.

3 Up to 10 per cent of the predetermined drawing amount could be disbursed without linkage to the International Monetary Fund facilities for a predetermined period-for example, 180 days.

4 The supplemental reserve facility is an additional borrowing facility where the maturity is shorter (one year as opposed to three years) and the interest rate higher than the usual facility.

5 Under the New Miyazawa Initiative, at least two measures were directly related to credit enhancement programs, that is, support for Asian countries in raising funds from international financial markets through the use of guarantee mechanisms, and possible establishment of an international guarantee institution with a primary focus on Asian economies. Unfortunately, there has been little follow-through on these programs.

6 The Asian Development Bank's current credit guarantee facilities are for projectspecific funding purposes and although the idea of Japan Bank for International Cooperation's credit guarantee was floated in the New Miyazawa Initiative no progress has yet been made.

7 See Jang et al. (2002) for the implications of launching of an Asian common currency for the development of a regional bondmarket.

8 EMEAP Group's 11 members are Australia, China, Hong Kong SAR, Indonesia, Japan, Korea, Malaysia, New Zealand, Philippines, Singapore and Thailand.

9 Japan's Ministry of Finance also supports the idea of ABC bonds (Taniguchi 2003).

10 Recent communications with a leading municipal bond insurer, $A M B A C$, indicate that it has offices in London, Tokyo and Sydney, offering complete regional coverage of structured deals (not municipal or government issues) outside the United States.

11 Cash reserve funds or excess servicing spread accounts are common internal credit enhancement methods, but they are usually combined with external enhancement programs such as letters of credit and third party guarantees (Fabozzi et al. 1997).

12 Collaterised bond obligations are the same as the collateralised mortgage obligations introduced by the Federal Home Loan Mortgage Corporation in 1983 to expand the mortgage-backed securities markets in the United States. Collateralised mortgage obligations originally took the form of sequential-pay tranches with different maturities to appeal to institutional investors with preferences for instruments of different maturities.

13 One caveat is in order, for the collaterised bond obligation scheme simply reallocates risk between two tranches of $\mathrm{ABC}$ bonds; it does not reduce or eliminate risk. In a recent credit card industry crisis in Korea, the collaterised bond obligation scheme backfired to create potential financial risk in systemic proportion, forcing the Korean government to bail out the industry in April 2003.

14 For an overview of capital market reforms in the region, see Rhee (2000).

15 The regular issuance of Exchange Fund papers in Hong Kong SAR was substantially curtailed as of September 1998 to ensure that new issues of Exchange Fund Bills and Notes were fully backed by foreign reserves, in accordance with the discipline of the Currency Board system, except when there are significant inflows of funds. Beginning in June 1999, the Hong Kong Monetary Authority resumed issuance of 10-year Exchange Fund Notes and simultaneously reduced the issue size of short-term Exchange Fund Bills by the same amount, thereby leaving the overall size of the Exchange Fund Bills and Notes portfolio intact.

16 As of December 2002, Japanese Government bonds held by households accounted for 2.4 per cent of total outstanding volume.

17 Scripless settlement for corporate bonds has yet to be implemented in Japan.

18 With this system now in place, US dollar checks are settled in two days, rather than in two weeks as in the past (see Hong Kong Monetary Authority 2000a, 2000b). 